\title{
Influence of corporate social responsibility (CSR) on safety culture
}

Ph.D. Eng Adam Górny Poznan University of Technology Department of Management Engineering

\section{Introduction}

In a changing economic environment which is critical for the operation of businesses, it is essential to identify approaches with a potential to boost enterprise value. One factors of central importance for the market standings of businesses is having a welldeveloped organization culture. A component of organization culture that is vital for occupational safety is safety culture.

Without a doubt, the principles of social responsibility and sustainable growth have recently become instruments for improving the image of quality-oriented organizations (Chojnacka 2010, pp. 39-54). One may conclude, therefore, that such principles are equally important for developing organization culture, including the culture of safety. Assuming that a business enterprise seeks to prevent fraud and neglect in the course of its operation (Jackson 1999, pp. 2127), thus contributing to the development of a corporate culture, it is only natural to conclude that the culture of safety will emerge as part of such development. Since it is bad and immoral to incur losses, any losses caused by an inappropriate safety culture may also be considered to be bad 
and immoral. A study of factors which contribute to safety and help establish the related culture shows that a number of such factors may be linked to social responsibility. As the components of social responsibility grow in their significance and rank in a given corporate organization, so does the importance of its safety culture which, after all, is a measure of how employee-oriented a given enterprise really is.

This paper suggests using certain significant features of social responsibility to develop a safety culture seen as the part of an organization's culture which defines its principles and guidelines for operation in a specified environment. The deliberations presented herein are designed as contributions to literature. They have been supplemented with observations made by the author in the course of conducting research projects (Górny 2012, pp. 287-304; Grzelczak, et al. 2012, pp. 109-138).

\section{The nature of safety culture}

\subsection{Organization culture as a foundation for safety culture development}

Organization culture is defined as adherence to rules with a view to achieve a specified goal. The notion extends to the recognition of values, standards and symbols which are characteristic of a given organization and developed with account taken of their influence on the organization's value system (Przybyła 2001, p. 32). An organization culture may be seen as an enterprise's personality manifested through all aspects of its operation (including behaviors of individuals and social groups and their mutual relationships) (Kostera, Kownacki 1995, pp. 297-299). Organization culture extends to unwritten and often subconscious principles which fill the space between written rules and reality (ZbiegienMaciąg 1999, p. 15). Organizations embrace such principles and are influenced by them in their activities. Organization culture may be seen in reference to views, behaviors, rules and identities of processes and behaviors which solidify social systems. The way in which a given organization approaches its activities affects the core of its organization culture (Bolesta-Kukuła 1995, p. 56) ultimately influencing its overall atmosphere.

The development of an organization culture in an enterprise ties inextricably to building a friendly atmosphere conducive to creating a community of workers and managers which is capable of effectively utilizing the available resources. To achieve this goal, the development of a working environment needs to be coordinated with the company's business strategy. The drive to 
create an organization culture in an enterprise has direct impact on how the organization as a whole and its individual members operate to meet their objectives.

It is by no means simple to accomplish goals. For change to be lasting and produce results, it is essential to recognize values and tenets as "one's own" and embrace them fully. The values, in their turn, manifest themselves through artefacts, i.e. the artificial external creations of a given culture which have been made evident and have become a part of the collective consciousness. Some such artefacts are physical and take the form of technologies and material objects. Organization culture is prerequisite for the proper operation of an organization. It is designed to reduce uncertainty. By ensuring that its employees are aware of and respect its principles, an organization satisfies their need for safety and affiliation (Kostera, Kownacki 1995, p. 303). Furthermore, organization culture allows enterprises to adjust themselves to their external environments.

A necessary condition for achieving the desired benefits is to act in concert in all fields of activity. Seen in this way, the working environment offers such benefits as (own study):

- protection of employee health and safety,

- work satisfaction,

- career development opportunities,

- jobs designed to match worker capabilities.

Associated with conditions in the working environment, such benefits should be seen as the minimum requirements needed to achieve desired and often previously unrealized outcomes in the form of paradigms of a company's organization culture. Once secured, they allow functions within the organization to operate smoothly and enable the organization itself to achieve the desired performance.

\subsection{Factors for developing a safety culture}

Safety culture is considered to be factors of an enterprise's organization culture. The term is to be defined to obtain a clearer view of the issue rather than arrive at a single universally applied concept. Safety culture is taken to represent a system of meanings which individuals, small groups and larger communities ascribe to hazards and the rules of conduct to be used in risk situations (Pidgeon, 1991, pp. 129-140). The safety culture concept is used in particular in sectors where safety deficiencies may cause enormous losses, often with global implications. These include the chemical and nuclear power industries. 
Safety culture defines "the human factor" as contributing to accidents and disasters, describing it as composed of multiple causes. The majority of accidents are preceded by fuzzy circumstances or multiple concomitant errors in the choice of technology, operation, the conduct of technical and other activities or result from multiple breaches of safety regulations. While individual breaches are usually not dangerous, multiple breaches accumulate to tip the scales and set the scene for a disaster (Pidgeon, 1991, pp. 129-140).

According to the guidelines of the Health and Safety Executive (HSE), safety culture brings together individual and collective values, behaviors, skills and standards of conduct with implications for the styles, quality and effectiveness of occupational health and safety management in a company (Successful health ... 1997, p. 14). According to Hale (2000, pp. 1-14), safety culture extends to behaviors, beliefs and views considered to be natural standards and values which define responses to high-risk situations and ways to manage them. A,I, Glendon and N.A. Stanton (2000, pp. 193-214) defined safety culture as attitudes, behaviors, standards, values and personal responsibility. Their approach to safety culture goes in the direction of human resource management. It rests on the assumption that safety can only be achieved with a strong collective commitment of a company's workers to measures designed to avoid perilous behaviors. Such measures complement the use of reliable work designs, systems and procedures (Berg, Kopisch 2013, pp. 17-28).

Regardless of which definition is chosen, safety culture is certain to have impact on every member of an organization assigned to the day-to-day effort of improving safety. An assessment of a given organization's safety culture relies on factors falling within the three reference areas of (Gambalska-Kwiecień 2012, pp. 189-198):

- working environment (tools, machines, workplace arrangement),

- employee behaviors (compliance with occupational health and safety regulations, transfers of information, showing care for safety beyond the call of duty),

- worker attributes (knowledge, skills, motivations).

Safety culture may be described as a state of awareness of threats, standards of conduct in risk situations and technical and organizational methods of ensuring worker safety and the protection of worker health and lives. Such culture covers individual convictions and values regarding human life and health and a sense of urgency to strive for achieve a desired safety level (Studenski 2000, pp. 1-4). Seen in this manner, safety culture defines the society's (stakeholders') views on risks and acceptable behaviors in emergencies and 
on recklessness. Furthermore, safety culture determines the legal standards, knowledge and education concerning safety and the consideration of safety in choosing technologies.

Admittedly, a company's safety culture is the awareness of risks on the part of the majority of its employees. Such culture describes formal and informal procedures applied in emergencies. A safety culture relies on the technical and organizational achievements which improve safety levels and health protection and on solutions applied in company management, work organization, employee supervision and evaluation and investigating the causes of accidents and disasters. Every enterprise develops its own unique safety culture defined by the employer, affecting its ability to spot hazards, take mitigation efforts and realize potential consequences (Oleszak 2012, pp. 181-189). Such culture satisfies the fundamental human need for safety which, next to the satisfaction of basic physiological needs, motivates workers to strive for higher goals.

An individual's safety culture expresses his or her individual views and values regarding their lives and health and the degree to which they should be protected. An individual's safety culture reflects individual views on perils, the tolerance for reckless behaviors, and the accepted patterns of behavior in high risk situations. It also affects up-front evaluations of such behaviors by co-workers and supervisors. Individual safety culture also defines the degree to which a given person has acquired formal standards of safety and conduct. Superior safety culture can be found in companies whose employees proactively and continuously care for their own safety and that of their co-workers beyond the call of duty (Oleszak 2012, pp. 181-189).

Of equal importance in developing a culture to govern a company's operations is to account for the ergonomics of work and ensure that loads are optimally adjusted. Ergonomics may be viewed as tied closely to the values which underpin safety culture. As such, ergonomics contribute to establishing best working conditions for all workers. To that end, an enterprise needs to recognize the human factor as central for its efforts. The human factors should be seen as crucial for its development and for the effectiveness of its activities. Changes in work techniques and organization and in technologies which ignore culturebased human behaviors are likely to fail to produce the expected outcomes. The most common direct reason for this is recklessness on the part of the organization's workers.

On the other hand, by taking proper account of ergonomic considerations in designing working conditions, an organization will improve its safety levels as 
it will recognize the physical capabilities and psychological profiles of workers, especially with respect to interactions with the physical and technological environment in which they work (Górny 2010, pp. 378-379). To achieve the required level of safety culture, an enterprise must invest in employee culture, motivate its workers to behave properly, educate and train them and simplify its occupational safety rules and procedures. A number of social benefits can be named that result from such an approach. These include increased worker awareness and motivation and a positive image of the company among client, business partners and society at large.

\section{Impact of corporate social responsibility on safety culture}

\subsection{Nature of corporate social responsibility (CSR)}

While the term social responsibility has only been in common use since the early 1970s, business organizations have been making efforts to make improvements in a number of the aspects it recommends even in the late $19^{\text {th }}$ century. By adopting the solutions proposed in the rules of social responsibility, organizations can take advantage of new ways of doings things and solving problems. At its basic level, social responsibility may be described as a set of an organization's obligations to protect and strengthen the social aspects of the environment in which it operates (Griffin 2004, p. 117). Corporate social responsibility may also be seen as moral responsibility towards all of an organization's internal and external stakeholders. Of particular significance is the impact on primary stakeholders (Zbiegień-Maciąg 1991, pp. 48-49). These include (Carroll 1993, p. 62) suppliers, shareholders, customers and employees. For each of these groups there is an adequate level of corporate responsibility and a set of proper measures that need to be taken.

Every company wishing to retain its market position needs to fulfil the obligations that arise from its specific scope of responsibility. It therefore needs to exercise due care in its actions which together make up a comprehensive pro-active process of identifying current and potential future negative social, environmental and economic implications of its decisions and actions (PN-ISO 26000:2012). The ultimate aim of the process is to avoid and mitigate the adverse impacts of change.

Of particular importance for the matter at hand is the definition of CSR formulated by the United States-based organization Business for Social Responsibility (BSR), which describes CSR as recognizing ethical values which 
conform to the law and embody respect for people and the environment (Business for ..., 2004). At the core of social responsibility is a method of managing the environment to ensure proper care for social, environmental, economic and ethical issues, satisfy stakeholder expectations and achieve the desired results.

A pivotal role in evaluating environmental impact is played by rules enshrined in ISO 26000 which point to the need to seek sustainable growth and prosperity for society at large. Such rules offer assistance in formulating guidelines for acting responsibly and transparently (Adamczyk 2009, pp. 177-188). The outcomes achieved through such efforts demonstrate they are closely aligned with the results sought by establishing a safety culture. Breakthroughs in formulating social responsibility guidelines comes at the point at which an organization embraces socially responsible goals and social values (Kaźmierczak 2009, pp. 10-13) without compromising its care for improving the quality of life of workers who are seen as a significant group of stakeholders. Organizations are required to disclose the identities of their stakeholders and consider their views in their decision-making even if the stakeholders play no formal role in managing them or are unaware of their interests.

\subsection{Potential influence of CSR on safety culture}

A particular role among the improvements which result from following the rules of social responsibility is played by the rules that help increase employee satisfaction with their working environment. Conformity with such rules can be trusted to be the key criterion for improving an enterprise's safety culture as well as its ability to achieve specified benefits.

The benefits of a proper approach to responsibility and of adopting an appropriate organization culture include (Górny 2003, pp. 381-382; Górny 2010, pp. 381-382):

- comfortable working conditions which contribute to the good health of employees,

- adherence to occupation safety rules ensuring that employees are properly treated,

- unrestricted access to various forms of employment,

- protection against adverse consequences of the organization's activities.

Note that work is not a commodity (ILO Constitution... 1944). In other words, the worker must not be viewed as a production factor governed by the same market rules as goods. A key responsibility emanating from the rules of 
social responsibility is to create jobs with respect for worker rights. Hence, organizations should be obliged to incorporate safety requirements and ergonomic criteria into the rules of social responsibility (Górny 2010, p. 383). It is often next to impossible to accomplish the benefits associated with healthy working environments without recognizing ergonomic criteria. To benefit truly, an organization needs to learn and identify worker expectations, in particular with respect to their working comfort.

To ensure that a socially responsible approach effectively influences the development of a safety culture, an organization should identify links and issues associated with the methods and scope of decision-making. Among the crucial factors for accomplishing the desired benefits are (PN-ISO 26000:2012):

- enterprise type and size and the nature of its business,

- the place of business, including, in particular, the social, environmental and economic profiles of the geographic areas in which a company pursues its business activities,

- the profile of the labor force/employees carrying out work,

- the organization's mission, vision, principles and codes of conduct,

- areas of interest for internal and external stakeholders,

- decision-making structures in place in the organization and the nature of its decision-making processes.

A central practical consideration in an expertly managed company whose working conditions are satisfactory in organizational and technical terms is to integrate its (Górny 2010, pp. 384-385):

- tangible working conditions i.e. material factors (basic machinery and equipment, supplementary equipment, working facilities), physical factors (lighting, temperature, noise, mechanical vibrations, radiation), chemical, organic and biological factors (fumes, gases and aerosols),

- work organization covering the division of labor, work schedules and rules governing work performance,

- economic and social aspects of the performance of work.

A reference to social responsibility criteria also allows organizations to find a link between the above issues and the safety culture improvements they achieve. While it is not easy to establish a linear relationship between specific actions and outcomes, there is no doubt as to the potential for improvements in safety culture (Studenski 1996). Table 1 shows actions respecting the rules of social responsibility which help reinforce the impact of safety culture on a company's competitive position. 


\section{Table 1. Examples of social responsibility efforts aimed at improving safety culture}

\begin{tabular}{|c|c|}
\hline $\begin{array}{l}\text { Safety culture } \\
\text { evaluation criterion }\end{array}$ & Actions compliant with social responsibility \\
\hline $\begin{array}{l}\text { Communication to notify work- } \\
\text { ers on existing hazards }\end{array}$ & $\begin{array}{l}\text { - all concerned persons notified on hazards at their workstations as pre- } \\
\text { scribed by law, } \\
\text { - occupational health and safety hazards arising within organization and } \\
\text { at workstations examined and monitored, } \\
\text { - particular attention given to vulnerable groups in view of the nature } \\
\text { of hazards }\end{array}$ \\
\hline $\begin{array}{l}\text { Involvement of the manage- } \\
\text { ment in improving occupational } \\
\text { safety, their interaction and care } \\
\text { for worker safety }\end{array}$ & $\begin{array}{l}\text { - proper conditions created to ensure that work can be performed in dig- } \\
\text { nity and that no benefits are derived from work-related abuse, } \\
\text { - adverse impacts of activities on occupational safety reduced, } \\
\text { - employer refrains from shunning its legal responsibilities towards } \\
\text { workers, } \\
\text { - occupational health and safety policy formulated, implemented and } \\
\text { maintained in keeping with the principle that strict safety rules and } \\
\text { company operations complement each other, } \\
\text { - action taken to eliminate psychological and social hazards at the work } \\
\text { place contributing to stress and illnesses }\end{array}$ \\
\hline $\begin{array}{l}\text { Occupational health and safety } \\
\text { education offered to an extent } \\
\text { reflecting the nature of work and } \\
\text { worker needs }\end{array}$ & $\begin{array}{l}\text { - all workers offered proper training accordingly to their needs, } \\
\text { - access provided to accurate up-to-date information on the measures } \\
\text { taken to improve safety, } \\
\text { - all workers at any stage of employment provided opportunities to im- } \\
\text { prove their skills, hands-on and theoretical training and career advance- } \\
\text { ment opportunities on equal non-discriminatory terms }\end{array}$ \\
\hline $\begin{array}{l}\text { Motivating workers to behave } \\
\text { safely, distinguishing employees } \\
\text { who abide by safety rules }\end{array}$ & $\begin{array}{l}\text { - workers put in a position where they can adhere to safety practices and } \\
\text { follow applicable safety procedures, } \\
\text { - rules of conduct and management systems rely on informed consent and } \\
\text { involvement of workers, } \\
\text { - workers and supervisors free to discuss occupational safety and moti- } \\
\text { vate workers to promote occupational safety as they see fit }\end{array}$ \\
\hline $\begin{array}{l}\text { Cooperation ensured among } \\
\text { workers, trust maintained be- } \\
\text { tween management and workers } \\
\text { and among workers }\end{array}$ & $\begin{array}{l}\text { - all workers provided with equal growth opportunities, direct and indi- } \\
\text { rect discrimination eliminated from work practices, } \\
\text { - the significance of social dialogue for the organization and the workers } \\
\text { duly recognized, } \\
\text { - workers, their representatives and the management involved in promot- } \\
\text { ing health and safety }\end{array}$ \\
\hline
\end{tabular}

Source: author's research, based on PN-ISO 26000:2012 guidelines 
It should be noted that the quality of life ensured in an organization, also with respect to the working environment, results from free, informed and deliberate trade-offs between technical, economic, organizational and socio-technical measures. The efforts result in the physical and personality development of individuals. People form the basic link in the chain of relationships determining the operation of any organization unit. As a consequence, they must be treated with full respect of the rules of social responsibility.

\subsection{Outcomes and benefits of CSR influence on safety culture}

Although not every enterprise, including those operating in this field, has a proper understanding of CSR, its rules are becoming ever more common (Stachowicz-Stanusch 2006, p. 510). To embrace such rules, an organization needs to recognize the specific characteristics of the field in question. Some of the crucial features of social responsibility linked to the rules of safety culture include (Gasiński, Piskalski 2004, pp. 19-20):

- maintaining a good relationship between employees and management,

- respecting industry rules and regulations,

- ensuring good relations in the workplace,

- properly compensating employees for overtime,

- ensuring appropriate working conditions (including occupational safety),

- maintaining a proper relationship with local communities,

- caring for the natural environment and recognizing its influence on working conditions.

The aim of monitoring actions associated with social responsibility is to show all those concerned that such actions are conducted as intended and contribute to identifying crises and modifying established procedures. Keeping continuous track of changes in the environment and changing expectations is to help identify new opportunities in the realm of social responsibility so as to ensure the organization benefits in all aspects of its activities. The extent of such efforts will vary depending on the company's business profile, its size and nature and other factors which affect the end results, such as meeting the expectations of the concerned parties.

Care for the environment is of essential importance for business organizations. To achieve the related goals, an enterprise needs to make social responsibility an integral part of its operating strategy (Zapłata, Kaźmierczak 2011, pp. 162-163).

Furthermore, an enterprise which wishes to be recognized as socially responsible should focus on treating its employees right as its top priority. 
This is because any company's key asset are its people. It is therefore critical to ensure they can operate in proper conditions within their working environment. Requirements in that respect include a safety culture which defines the scope and methods of conducting systemic measures. Sample questions designed to help assess such measures are provided in table 2. Opportunities for developing a safety culture should be identified by seeking a proper reputation and credibility in the spirit of the rules of social responsibility.

\section{Table 2. Sample criteria for evaluating systemic measures taken to implement the principles of safety culture}

Have the target goals and values pursued to ensure proper working conditions been achieved and upheld as planned?

Have appropriate strategies been adopted and have the procedures necessary to accomplish the goals set out in such strategies been followed?

Have safety objectives been implemented effectively so as to allow the achievement of the desired outcomes?

Have the adopted safety objectives been properly formulated?

Are any areas and task implementation processes in need of improvement?

Have all persons needed to ensure that processes are properly followed and tasks properly carried out been engaged?

Source: author's research

Some of the common outcomes of applying the above approach include (Górny 2012, p. 294):

- broad-based care for the working environment exceeding mandatory legislative requirements,

- training in fields related to the nature of work in relevant jobs,

- the development of professional competencies, especially with respect to the ability to perform work safely,

- care for employees exercised by, among others, emphasizing prevention in occupational safety,

- employee health-care plans (including extra check-up and vaccination schemes),

- effective communication (including information on occupational health and safety perils and professional hazards), 
- the use of technical and organizational measures to protect employees against hazards,

- development of a culture comprised of procedures for responding to hazards and strenuousness.

By applying the principles of social responsibility in the development of a safety culture, organizations can define the actions which help them eliminate shortcomings and improve performance.

\section{Conclusions}

Corporate social responsibility is enjoying increasing popularity in today's world of tight competition. It is employed by ever more enterprises which seek to achieve a lasting competitive advantage on the global market.

In keeping with the principles of corporate social responsibility, organizations may identify procedures they need to apply in relations with their internal and external partners to improve the way such partners carry out their responsibilities in all fields of impact on the environment. A responsible approach to society in all areas of impact is a crucial prerequisite of social responsibility. Such an approach should incorporate actions which will ensure the harmonious social and economic development of the world, including the natural environment.

By adopting the principles of social responsibility, an enterprise will benefit all its stakeholders. To achieve the desired outcomes, businesses need to identify procedures and define opportunities for influencing other significant areas affected by their activities. Much emphasis in this respect should be placed on the impact of safety culture, which constitutes a yardstick of the effectiveness of such efforts made to ensure occupational health and safety as employee selection for particular positions, professional training and improvement, motivating employees for safety, adopting changes, and rapidly responding to developments which have an adverse effect on safety to restore the desired state (Studenski 2000, pp. 1-4).

Arguments in favor of the above approach can be found in important guidelines followed in developing social responsibility principles. A key role in formulating social responsibility standards is played by conventions and declarations of the International Labor Organization (ILO). The guidelines set out in ILO regulations may well be seen as a major argument for building a safety culture linked with social responsibility principles. Such guidelines may also be seen as motivators to work safely which modify worker behaviors. 


\section{Abstract}

\section{Influence of corporate social responsibility (CSR) on safety culture}

Both safety culture and corporate social responsibility are essential drivers of enterprise value. By recognizing and adopting the principles of social responsibility, an organization may achieve a lasting competitive advantage on its markets. In their overall efforts, organizations must not ignore the need to care for the working environment and treat their workers in a proper way. As it turns out, measures conducted in the pursuit of social responsibility may be derived from a company's emerging safety culture, which is equally important for an enterprise's competitive position.

Keywords: social responsibility, safety culture, management, competitive advantage.

\section{Streszczenie}

Wpływ odpowiedzialności społecznej przedsiębiorstwa (CSR) na kształtowanie kultury bezpieczeństwa

Zarówno kultura bezpieczeństwa, jaki społeczna odpowiedzialność przedsiębiorstwa są czynnikami pozwalającymi na wzrost wartości przedsiębiorstwa. Szczególnie uwzględnienie zasad odpowiedzialności społecznej może przyczynić się do osiągnięcia trwałej przewagi konkurencyjnej na rynku. W podejmowanych działaniach nie można pominąć dbałości o środowisko wykonywania pracy oraz odpowiednie traktowanie zatrudnionych. Okazuje się bowiem, że realizacja działań zgodnych z koncepcją społecznej odpowiedzialności może być przejawem kształtowanej kultury bezpieczeństwa, równie ważnej dla pozycji konkurencyjnej przedsiębiorstwa.

\section{Słowa \\ kluczowe: odpowiedzialność społeczna, kultura bezpieczeństwa, zarządzanie, przewaga konkurencyjna.}

\section{References}

1. Adamczyk J. (2009), Społeczna odpowiedzialność przedsiębiorstw. Teoria i praktyka, PWE, Warszawa. 
2. Berg H.-P., Kopisch Ch. (2013), Safety Culture and its Influence on Safety, "Journal of KONBiN", vol. 23 (1).

3. Bolesta-Kukułka K. (1995), Świat organizacji, w: A.K. Koźmiński, W. Piotrowski (red.)., Zarzadzanie. Teoria i praktyka, Wydawnictwo Naukowe PWN, Warszawa.

4. Business for Social Responsibility (2004), Overview of Corporate Social Responsibility, BSR Issue Briefs,:http//www.bsr.org/BSRResources/ IssueBriefDetail.cfm?DocumentID=48809 (29.11.2004 - date of file transmission).

5. Carroll A.B. (1993), Business and Society. Ethics and stakeholder, College Division South-Western Publishing Co., Cincinnati.

6. Chojnacka M. (2010), Idea społecznej odpowiedzialności, etyki i zrównoważonego rozwoju jakoinstrumentksztattowania wizerunku przedsiębiorstwanaprzykładzie polskich organizacji projakościowych, w: Skrzypek E. (red.), Problemy etyczne w organizacji uczącej się, Uniwersytet M. Curie-Skłodowskiej w Lublinie, Lublin.

7. Gambalska-Kwiecień A. (2012), Ksztattowanie kultury bezpieczeństwa w przedsiębiorstwie, Zeszyty Naukowe Politechniki Śląskiej, seria: Organizacja i Zarządzanie", z. 63a, nr 1891, Gliwice.

8. Gasiński T., Piskalski C. (2004), Zrównoważony biznes. Podręcznik dla małych $i$ średnich przedsiębiorstw, Ministerstwo Gospodarki, Warszawa.

9. Glendon A.I, Stanton N.A. (2000), Perspectives on safety culture, "Safety Science", No 34.

10. Górny A. (2003), Ergonomia $i$ bezpieczeństwo pracy w nowoczesnym zarządzania jakościa, w: M. Fertsch, S. Trzcieliński (red.), Praktyka zarzadzania nowoczesnym przedsiębiorstwem, Instytut Inżynierii Zarządzania, Politechnika Poznańska, Poznań.

11. Górny A. (2010), Ergonomia w ksztattowaniu społecznej odpowiedzialności biznesu, w: E. Skrzypek (red.), Problemy etyczne w organizacji uczacej się, Uniwersytet M. Curie-Skłodowskiej w Lublinie, Lublin.

12. Górny A. (2012), Znaczenie determinant bezpieczeństwa pracy i ochrony zdrowia zatrudnionych w rozwoju społecznej odpowiedzialności przedsiębiorstwa, w: K. Borodako, M. Nowosielski (red.), Forsight w praktyce zarządzania przedsiębiorstwem. Analizy i studia przypadków, Instytut Zachodni, Poznań.

13. Griffin R.W. (2004), Podstawy zarzadzania organizacjami, Wydawnictwo Naukowe PWN, Warszawa.

14. Grzelczak A., Borowiec A., Górny A. (2012), Forsight przedsiębiorstw. Zastosowanie metodyki myślenia sieciowego, Wydawnictwo Politechniki Poznańskiej, Poznań.

15. Hale A.R. (2000), Editorial: culture's confusions, "Safety Science”, No. 34.

16. International Labor Organization (1944), ILO Constitution (including Declaration of Philadelphia), Philadelphia. 
17. Jackson J. (1999), Biznes i moralność, PWN, Warszawa.

18. Kaźmierczak M. (2009), Bezpieczeństwo i higiena pracy a rozwój odpowiedzialności społecznej, „Bezpieczeństwo pracy”, nr 5.

19. Kostera M., Kownacki S. (1995), Kierowanie zachowaniami organizacyjnymi, w: A.K. Koźmiński, W. Piotrowski, Zarzadzanie. Teoria i praktyka, Wydawnictwo Naukowe PWN, Warszawa.

20. Oleszak W. (2012), Kultura bezpieczeństwa w środowisku pracy, „Edukacja Humanistyczna", nr 1(26).

21. Pidgeon N.F. (1991), Safety culture and risk management in organization, "Journal of Cross-Cultural Psychology", No. 22.

22. PN-ISO 26000:2012, Wytyczne dotyczace społecznej odpowiedzialności, PKN, Warszawa.

23. Przybyła M. (2001), Organizacja i zarządzanie. Podstawy wiedzy menedżerskiej, Wyd. Akademii Ekonomicznej we Wrocławiu, Wrocław.

24. Stachowicz-Stanusch A. (2006), Zarządzanie odpowiedzialnościa społeczna w przedsiębiorstwie. Teoria i praktyka polskich przedsiębiorstw, w: K. Ziemniewicz (red.), Instrumenty zarządzania we wspótczesnym przedsiębiorstwie. Analiza krytyczna, Zeszyty Naukowe Akademii Ekonomicznej w Poznaniu, nr 81, Poznań.

25. Studenski R. (1996), Organizacja bezpiecznej pracy w przedsiębiorstwie, Wyd. Politechniki Śląskiej, Gliwice.

26. Studenski R. (2000), Kultura bezpieczeństwa w przedsiębiorstwie, „Bezpieczeństwo Pracy", nr 9.

27. HSE (1997), Successful health and safety management (1997), Health and Safety Executive, London.

28. Zapłata S., Kaźmierczak M. (2011), Ryzyko, ciagłość biznesu, odpowiedzialność społeczna. Nowoczesne koncepcje zarządzania, Oficyna Wydawnicza a Wolters Kluwer business, Warszawa.

29. Zbiegień-Maciąg L. (1991), Etyka w zarządzaniu, PWN, Warszawa.

30. Zbiegień-Maciąg L. (1999), Kultura organizacji, PWN, Warszawa. 